\title{
ВІЙСЬКА РОСІЙСЬКОГО ПІВДЕННО-ЗАХІДНОГО ФРОНТУ У ЧЕРВНЕВОМУ НАСТУПI 1917 року
}

У статті розглядається бойова діяльність російських військ ПівденноЗахідного фронту у червневому наступі 1917 року на українських землях під час Першої світової війни. Проаналізовано праці, у яких різною мірою висвітлюеться дане питання, умови підготовки та проведення наступу, простежено участь військ у бойових діях на фронті та вивчено їх внесок у результати боїв.

Ключові слова: Російська армія, Перша світова війна, кампанія 1917 р., армія, корпус, дивізія, піхота, артилерія, авіація.

Постановка проблеми та ії актуальність. Бойова діяльність російських військ Південно-Західного фронту під час наступу у червні 1917 р. залишається недостатньо висвітленою. А між тим вона займає помітне місце в історії Першої світової війни та воєнній історії України. Ії поглиблене вивчення дозволить розширити обсяг знань про тогочасні події, врахувати уроки революційних змін 1917 р. у тодішній діючій армії, а відтак, і в ході розбудови нащіональних збройних сил у теперішній час. Тому наявний військовий досвід столітньої давнини продовжує привертати увагу дослідників.

Аналіз попередніх досліджень і публікацій. Опрацювання даної теми здійснено у спеціальних наукових працях. Загальний перебіг бойових дій висвітлено у доробку А. М. Зайончковського [1, 12]. Він робить висновок, що 3 точки зору стратегії ці події з російської сторони не дають матеріалів для того, щоб на них зупинятися [1, с. 84]. Білњш детально перебіг червневого наступу висвітлено у 7-й частині «Стратегічного нариса війни 1914 - 1918 рр.», підготовленій цим же автором [1].

Загальні ощінки щодо дій всього Південно-Західного фрронту в цілому даються у працях радянських дослідників.

Науменко Андрій Олегович, кандидат історичних наук, старший науковий співробітник, начальник науково - дослідної лабораторії кафедри морально - психологічного забезпечення діяльності військ (сил), Нащіональний університет оборони України імені Івана Черняховського, м. Київ.

( ) Науменко А. О., 2017 
Остаточний неуспіх червневого наступу вони пов'язують із небажанням військ воювати, а також неможливістю забезпечити його несподіваність. На бойовій діяльності військ вони не зупиняються, приділяючи увагу лише загальному ходові військових подій червня 1917 р. Слід також зауважити, що у працях радянських дослідників досить точна хронологія подій $[3,22]$. Проте зазначимо, що у СРСР історики були позбавлені можливості поглиблено вивчати саме воєнну героїку 1917 р., оскільки перебували під потужним ідеологічним впливом, який дозволяв висвітлювати тогочасні події лише у контексті революції.

Приділяе увагу цим подіям історіографія російської білої еміграції. О. Будберг вдало визначив внесок російського фрронту у кампанії 1917 р. та його значення [5]. М. Головін в цілому коротко висвітлюе хід подій і визначає рівень підготовки наступу [9]. А. Керсновський, розкриваючи наступ червня 1917 р., лише коротко згадує приклади звитяги окремих військових частин, що у працях радянських дослідників майже не зустрічаються [16].

Сучасні дослідники певною мірою намагаються заповнити щю прогалину. Зокрема, побачили світ окремі статті та збірники матеріалів, біографічні довідники, які висвітлюють роботу вищого командування та бойову діяльність військ у 1917 р. Українська історична наука також зробила помітні кроки у цьому напрямку, різноаспектно розкриваючи події 1917 р. [6, 13, 14, 21]. В цілому ж історіографрія даного питання розкриває переважно бойову діяльність армій і подекуди корпусів, дивізії ж і полки залишаються поза увагою дослідників. Відтак, можна стверджувати, що бойові дії військ Південно-Західного фронту у червні 1917 р. недостатньо опрацьовані науковцями.

Важливий матеріал для дослідження міститься у мемуарах воєначальників Першої світової війни, зокрема О. Брусилова, Б. Геруа, Е. Людендорфа та інших [4, 8, 19]. Цінні відомості надаються білоемігрантськими виданнями, зокрема журналом «Военная быль». Зокрема для опрацювання даної статті використано праці В. Кочубея [17, 18]. Українські діячі, а саме Д. Дорошенко, В. Кедровський i 
М. Галаган, наводять цікаві спостереження у своїх спогадах $[7,10,11,15]$. Ці праці також певною мірою допомогли у висвітленні військових подій червня 1917 р. В цілому науковий доробок у поєднанні з вказаними та іншими джерелами дають можливість дослідити дане питання.

Мета та завдання статті полягає у висвітленні та аналізу бойових дій військ Південно-Західного фронту під час проведення наступу у період з 18 червня (1 липня) по 30 червня (13 липня) 1917 року.

Виклад основного матеріалу дослідження. На 1917 рік кожна 3 воюючих країн виношувала свої потаємні плани. Німецьке командування обрало оборонну тактику, керівництво Антанти - наступальну [21, с. 15]. Союзні держави вимагали від Росії негайного наступу. В свою чергу, Тимчасовий уряд у Петрограді не збирався ухилятися від цієї вимоги. При цьому терміни наступу неодноразово переносилися на всіх фронтах. Головна причина полягала у настроях військ, які вже не бажали воювати [22, с. 356-357]. Начальник штабу Верховного головнокомандувача генерал О. Лукомський вказував, що російські зобов'язання перед союзниками примушували росіян зовсім не відмовлятися від активних дій. Сподівання на успіх, хоча б і при короткому ударі, давала велика перевага їх сил на ділянщі удару порівняно з силами противника, яка виражалася у середньому співвідношенні 4 : 1, і велика перевага в артилерї, в т. ч. і важкій $[6$, с. 131].

Командуючим фрронтом був генерал О.Є. Гутор. Він характеризувався як «...бойовий генерал. Мало сидів в своїй ставці в Кам'янці, а все перебував на самому фрронті» [11, c. 125]. Також зазначається, що у Гутора були гарні військові якості: живість, рухливість, здатність прийняти розумне рішення, вміти на ньому наполягти i, якщо потрібно, ризикнути [8, с. 180]. Отже, цей військовий керівник відповідав своєму призначенню. Південно-Західний фрронт включав чотири армії, а саме: Особливу генерала П. С. Балуева XXXI, XLVI, XXXIX армійські і IV кінний корпуси, розтягнуті у Поліссі; 11-у генерала I. Г. Ерделі - I-й Туркестанський, V-й Сибірський, XXXII-й, XVII-й, XLIX-й, VI-й армійські і 
VII-й кінний корпуси - в районі Дубно - Броди; Командувача 11-ї армї генерала I. Г. Ерделі сучасники вважали гарним військовим [8, с. 180]. 7-у генерала Л. М. Бельковича XLI, XXXIV, XXII армійські, VII Сибірський, III Кавказький корпуси - в долині Гнилої Липи; і 8-у генерала Л. Г. Корнілова - XXXIII, XII, XVI армійські корпуси на Дністрі і Задністров'ї, XI , XXIII і XVIII корпуси в Буковинських Карпатах [13, с. 57, 73, 99, 137, 234; 16, с. 279].

Військам фронту було поставлено завдання розбити противника, що стояв на шляху до Львова. Головний удар завдавався силами 11-ї і 7-ї армій на ділянщі Поморяни, Бережани у загальному напрямку на Львів. 8-а армія, що забезпечувала операцію з боку Карпат, завдавала допоміжного удару своїм правим фрлангом на Калуш, Болехів. Особлива армія мала скувати противника, не допускаючи перекидання його сил на львівський напрямок. Атака призначалася на 18 червня (1 липня) [22, с. 358]. Це була третя спроба росіян захопити Львів за всю війну. Перша спроба у 1914 р. була успішною. Потім, після Великого відступу 1915 р., росіяни під час славетного Брусиловського прориву до Львова не дійшли. І от влітку 1917 р. мала місце третя спроба.

У період підготовки наступальної операції ПівденноЗахідного фрронту у смузі довжиною 100 км було зосереджено разом з фронтовими і армійськими резервами 32 піхотних і 8 кінних дивізій, які підтримувалися 1114 гарматами. Таке скупчення сил і засобів дозволяло довести щільність наступаючих до 2 - 2,5 дивізій і 30 - 35 гармат на 1 км фрронту. На ділянщі прориву 7-ї армії щільність артилерії сягала 44 гармати на 1 км фронту, включаючи важку артилерію особливого призначення, що вперше брала участь у бойових операціях [22, с. 358]. Особлива увага зверталася на розробку артилерійського вогню. Цим займався здібний артилерист полковник Ф. Кірей [8, с. 184]. Управління артилерією було повністю централізовано. 3 метою забезпечення більшої дієвості її вогню використовувалися найновіші для того часу органи звукової, світлової та топографічної розвідки, а також авіація [22, с. 358]. Б. Геруа свідчить, що відносно кількості зосереджених для атаки сил вдалося 
досягти арифрметичної переваги у піхоті майже удвічі. «Але поправкою до арифметики на користь наших противників було те, що вони не відзначали, як ми, свято революції» [8, c. 185]. Таким чином далекоглядні російські воєначальники, а таких в армії було не так уже й мало, все ж розцінювали вплив револющійного фактора на настрої російських військ як негативний. В недалекому майбутньому вони не помилилися в оцінці своїх військ і військ противника.

Проводилися й інші заходи. Д. Дорошенко зазначає: «По фрронті їздили комісари і виголошували промови на тему про необхідність наступати, подолати ворога і цим закінчити війну та закріпити «надбання революції». При џьму він же вказуе і на українські сподівання: «Ми, українщ, тепер також бажали цього успіху: була думка, що коли вдасться захопити всю Галичину, то вже вдержимо иї в своїх руках, і тоді справді Галичина приєднається до вільної України у вільній Росї» [11, с. 131]. У зв'язку з цим Голова Українського Генерального Військового комітету С. Петлюра навіть видав відозву, в якій закликав: «припинити наступ німців і не пускати їх на нашу землю... як одженемо німців, як зупинимо наступ їх, то спасемо Україну, спасемо нашу землю, наше хазяйство, наших дітей, батьків і жінок, нашу волю, наше право на вільне життя. Коли ж нічого не будемо робити в цій справі, то неславно загинемо і загубимо Україну. Проклянуть нас діти наші і не признає нас Україна за своїх синів». Цей заклик таки вплинув на настрої вояків-українців. Д. Дорошенко вказує, що в ході наступу українці билися якнайкраще, що визнавалося командуванням і в подальшому змінило його погляд на українізацію військ [10, с. 369].

А. Зайончковський підсумовуе, що літній наступ 1917 р. пройшов загалом під знаком мітингів, умовлянь і повного в цьому відношенні єднання між Керенським і командирами, що вели війська у бій з частим прикриттям командирів комісарами і комітетами [1, с. 69]. О. Брусилов свідчить, що: «при об'їзді Юзфронту Керенським його майже скрізь приймали гаряче і багато йому обіцяли. Але коли дійшло до справи, то, взявши спочатку окопи противника, 
війська затим наступного дня повернулися назад, оголосивши, що оскільки анексій і контрибуцій вимагати не можна і війна до переможного кінця неприпустима, то вони і повертаються на свої старі позиції» [4, с. 277]. Безпосередньо у частинах ситуація носила майже критичний характер. Майбутній гетьман України, а тоді командир XXXIV-го армійського корпусу (у подальшому - 1-го Українського) генерал-лейтенант П. Скоропадський писав: «Озвірілі солдати мітингували, збившись у натовп. Необхідно було в'їжджати або входити у середину юрби і переконувати. ...» [23, с. 58]. М. Галаган свідчить «Наш 18-й Заамурський полк, ..., частинно зовсім відмовився йти в наступ, частинно був розтрощений» [7, с. 238]. На час початку наступу переважна більшість російських військ була саме у такому стані та у командування мало залишалося сподівань, що цю ситуацію вдасться виправити. Заходи пропаганди, що проводилися у військах, за невеликим винятком, бажаних результатів не дали.

Тим не менше наступ розпочався. 16 (29) червня артилерія Південно-Західного фрронту відкрила вогонь по позиціях австро-німецьких військ. Артилерія буквально знищила всі укріплення противника. Тільки тоді рушила російська піхота вперед, при чому сам наступ у сорері вогню противника вівся головним чином тільки відбірними частинами [9, с. 471]. 18 червня (1 липня) в атаку було кинуто піхоту 11-ї і 7-ї армій. Перші два дні принесли наступаючим певний тактичний успіх. На окремих ділянках було захоплено 2-3 лінії окопів противника. Е. Людендорф, характеризуючи російський наступ, вказує, що він супроводжувався великим розходом бойових припасів, атаки провадилися щільними масами. Він же твердить, що австро-угорські війська масово здавалися у полон. Там, де були розташовані австро-угорські війська, російський наступ мав успіх, а де німецькі і турецькі - ні [19, с. 434].

Разом $з$ тим, XLIX корпус 11-ї армії оволодів с. Коржилів, a XVII - с. Пресовці. Армія мала мщно утримуватися лівим фрлангом на лінії Конюхи-Бишки і розвивати прорив у 
загальному напрямі на Жабін. У бій вводиться і I гвардійський корпус (з резерву фрронту), якому наказано було оволодіти Жабинськими висотами. VI корпус міцним ударом поблизу Конюхів прорвав фрронт 25-го австро-угорського корпусу на стику II австро-угорської та Південної німецької армій. VI корпус складався з п'яти дивізій (4-ї, 16-ї, 151-ї, 155-ї і 2-ї Фінляндської), проте весь тягар операцій ліг на дві його корінні дивізї, особливо на 4-у. Було взято 5000 полонених і 10 гармат [16, с. 284]. А. Керсновський наголошує на діях 4-ї дивізї, не згадуючи про інші, а між тим 155-а піхотна дивізія генерал-майора М.П. Коломенського (617-й Зборівський, 618-й Тернопільський, 619-й Золочівський, 620-й Ново-Алексинський піхотні полки), за даними В. Кедровського, втратила 3/4 свого складу, але з честю вийшла 3 тяжких обставин [13, с. 504; 14, с. 860; 15, с. 273]. В. Кедровський свідчить: «Про геройство їі писала вся російська преса; було надруковане не одне похвальне урядове повідомлення командування про її знамениті бої, але ніде жодним словом не було згадано, що то українська дивізія, в якій москалів не було». Він же свідчить, що коли національні частини провадили наступ, то у спину їм стріляли вояки вже розкладених російських частин, що перебували під потужним пропагандним впливом більшовиків [15, с. 273-274].

Під час наступу активно діяла авіація, зокрема 17 (30) червня 1-й бойовий загін С. М. Нікольського, що складався 3 трьох літаків - «Київський», 14-й і 15-й здійснив бойовий виліт. Першим полетів 14-й, придушуючи кулеметним вогнем вогонь зенітеної артилерії. Крім того, ця група зкинула бомби на станщію Липиця-Дальня, i знищивши все, що там знаходилося, повернулася на свій аеродром [20, с. 129, 288-289]. Загалом пілоти виконували по 2-3 вильоти на день, а деякі і по 4-5. Відзначився і 7-й авіаційний загін винищувачів корнета Ю. Гільшера. В результаті успішних дій цього підрозділу літаки противника часто змушені були вертатися назад, так і не виконавши 
завдання. Особливо у цих боях відзначилися прапорщик Янченко і поручик Макейонок. Вже на другий день наступу, 19 червня (2 липня), прапорщик Янченко збив ворожий літак-корегувальник, чим значно ускладнив завдання важкої артилерії противника, яка завдавала значних втрат російським військам [2, с. 44].

19 червня (2 липня) генерал Ерделі завдав сильного удару XLIX корпусом генерала В. I. Селівачова по 9 австроугорському корпусові під Зборовом. Генерал В. I. Селівачов характеризувався сучасниками як спритний, розумний та енергійний начальник [8, с. 186]. У XLIX армійський корпус входили 4-a i 6-а Фінляндські стрілецькі, 82-а піхотна дивізії і Чехословацька бригада полковника Троянова. 4-а Фінляндська дивізія завдала удару по 32-й угорській i 223-й німецькій піхотній дивізіям і чехословаки - по 19-й австро-угорській дивізії, що значною мірою складалася 3 чехів. Фінляндські стрільці взяли сильно укріплену гору Могила. Особливо відзначився 13-й Фінляндський стрілецький полк полковника Папчинського, що взяв 1500 полонених i 6 гармат. Чехи відкинули у тричі сильнішого противника i взяли 6000 полонених і 15 гармат (втративши 150 вбитими i 1000 пораненими з 5000). 22 червня (5 липня) частини XVII і XLIX корпусів знов атакували, але не домоглися значних успіхів. Було захоплено 17 офіцерів і 1032 солдати [16, с. 283-284]. 11-а армія у Зборівському бойовищі 18 22 червня (1 - 5 липня) захопила 300 офіщерів, 18500 солдатів, 31 гармату і 33 кулемети [8, с. 191].

Разом $з$ тим, як свідчив генерал О. Лукомський, на фрронті 11-ї армії багато частин проявили велику звитягу, але розвинути успіх не могли, оскільки частини, що атакували, швидко виснажувалися і виявляли повну нездатність до продовження операції, а у частинах, які мали змінити i зайняти вихідне положення для подальшого наступу, виявилися неприпустимі у військовій справі порядки, коли частина замість того, щоб швидко і безумовно виконати відданий їй наказ, займається обговоренням, наскільки той наказ підлягає виконанню. Дорогоцінний час спливав, противник підсилювався і перегруповувався [6, с. 132]. 
7-а армія також у перший день боїв мала звичайний для початку прориву успіх на фронті Шибалин-Посухів, але зустрічний сильний спротив противника, а потім і ряд контратак припинив дальше просування і навіть примусив росіян на правому фрланзі поблизу Шибалина відійти у вихідне положення. На 19 червня (2 липня) армії наказано було відновити положення на фрронті Шибалин-Посухів i зосередити зусилля на західному березі Золотої Липи на фрронті Посухів-Ольховець [1, с. 69]. Війська 7-ї армї витримали впертий і успішний бій 18 - 19 червня (1 - 2 липня), у якому прорвали фрронт противника під Диким Ланом і завдали поразки 25-му німецькому резервному корпусові під Бережанами. Як і в 11-й армії, у бій було введено тільки 3 корпуси [8, с. 192]. Честь цих успіхів значною мірою належить частинам XXXIV армійського корпусу генераллейтенанта П.П. Скоропадського, що складався 3 23-ї піхотної, 19-ї Сибірської, 104-ї і 153-ї піхотних дивізій. Незважаючи на жорстокий спротив 15-ї і 24-ї резервних німецьких дивізій, корпус захопив три лінії німецьких позицій і таким чином у його руки перейшов увесь масив «Дикі Лани», що перекрили противнику підходи до Бережан. Тут відзначився 416-й Верхньодніпровський полк полковника Я.Г. Гандзюка, який особисто очолив атаку полку. Ці дії Верхньодніпровців захопили і решту частин 104-ї дивізії та деякі інші сусідні [17, с. 19]. Проте дана атака коштувала корпусові великих втрат, переважно тому, що інші війська в наступ не пішли. Три дні корпус утримував захоплені позиції противника. Коли ж німці підвезли свіжу 241 дивізію і направили свій контрудар у відкриті фрланги корпусу, Скоропадський наказав відійти у вихідне положення [18, с. 2324]. Тим часом XXII корпус (3-я і 5-а Фінляндські стрілецькі дивізії) спочатку збив 15 турецький корпус, але турецькою контратакою був повернутий у вихідне положення. Всього ж у перші два дні наступу 7-а армія взяла 23 офіцери і 198 солдатів полоненими. 24-а німецька резервна дивізія, яку розбила 3-я Заамурська, була знята 3 фрронту. Німці втратили 5454 бійців, з них 1982 полонених (22 \%), а 
турки - 32526 бійців тільки 191 полоненого (8 \%). А. Керсновський вважає це доказом високої боєздатності турецьких військ [16, с. 285].

Але потім просування припинилося. Війська почали обговорювати накази і мітингувати. Спроби відновити активні дії не дали позитивних результатів [22, с. 359]. Генерал О. Лукомський доповідав, що на фрронті 7-ї армії, де прийшлося зустріти переважно німщів, частини негайно, від одного тільки артилерійського вогню і при перших спробах противника здійснити контратаки, відійшли майже по всьому фрронту у вихідне положення, і повторити атаку вже не могли протягом всього подальшого часу [6, с. 131]. 23 червня (6 липня) 11-а армія після артилерійської підготовки знов перейшла в наступ і мала незначний тактичний успіх. На џому все зупинилося. 24 червня (7 липня)_командарм почав перегрупування, яке мало закінчитися на ранок 27 червня (10 липня) для нової атаки [1, с. 69].

Несподіваний успіх випав на долю 8-ї армії генерала Л.Г. Корнілова. III австро-угорська армія генерала К. Терстянського фон Надас, що протистояла Корнілову налічувала 6,5 піхотних і 1 кінну дивізії у своїх 26-му і 13-му корпусах. У командувача VII австро-угорської армї Г. Кьовесса фон Кьовесгаза було 11 піхотних і 3,5 кінних дивізї [16, с. 286]. Е. Людендорф вказує, що австро-угорські війська подалися назад; щойно прибула свіжа німецька дивізія намагалася зупинити відступ, але була захоплена загальним потоком [19, с. 434].

23 червня (6 липня) 8-а армія прорвала оборону противника південніше Станиславова, а 25 червня (7 липня) північніше цього ж міста. 23 червня (6 липня) XVI корпус (41-а, 47-а, 160-а піхотні, 7-а і 9-а кінні дивізіі) почав допоміжну атаку і збив противника 3 його передових позицій, захопивши їх на фрронті Ляховці-Дзвиняч i від Яблонки уверх по р. Бистриця. Тут корпус наступного дня відбив усі контратаки, а 25 червня (7 липня) почав наступ і XII корпус під проводом генерала В.А. Черемісова. Шість його дивізій (11-a, 19-а, 56-а, 117-а, 164-а піхотні та 1-а Заамурська прикордонна) вдало прорвали передову, проміжну і головну 
позищії противника на всьому фронті від Ямнищі до Загвоздя. В боях 26 червня (8 липня) було розбито новоприбулі німецькі підкріплення і відкинуто ХІІІ корпус. Південна німецька армія спішно загнула свій правий фрланг. Росіяни захопили 28 гармат і більше 7000 полонених [1, с. 70; 13, с. 221; 16, c. 286-287; 22, c. 359].

Прорив 8-ї армї швидко розвивався і у ньому, крім XII корпусу, взяли участь також на його правому флланзі XXXIII корпус і на лівому - XVI. Увечері 27 червня (10 липня) на правому фрланзі росіяни зайняли Галич і лінію р. Лімнищі до Калуського шосе; на лівому фрланзі XVI-й корпус зайняв лінію Невочин-Пороги. 28 червня (11 липня) зайнято Калуш. Зранку 28 червня (11 липня) 164-а піхотна дивізія, прикриваючись садами, без пострілу увійшла в Калуш. Німецькі війська, заскочені зненацька, втекли за Лімнищю, знищивши переправи. 164-а дивізія взяла більше 1000 полонених i 13 гармат [16, с. 287]. На 30 червня (13 липня) російські війська просунулися до лінії Копанка-Мостиська-ДовгеКамінь-Небилів-Грінки. На цей час наступальний порив армії згас, війська перепилися у Калуші, а противник встиг перекинути сюди резерви, і успіх 8-ї армії припинився. Цим закінчуеться перший період літніх операцій ПівденноЗахідного фрронту [1, с. 71, 73].

На 1-2 (14-15) липня наступ росіян завмер остаточно [9, c. 472]. При цьому три їхні армї втратили 1222 офіцерів і 37500 солдатів, що складало 14 \% всього складу [6, с. 132]. М. Головін вказує, що порівняно з втратами, які витримувала Російська армія до революції, ці цифри не є великими. Але, справа полягає в тому, продовжуе він, що ці втрати мають бути віднесені винятково на долю відбірних частин і тих нечисленних полків піхоти, котрі встояли від хвороби розкладу. В цьому разі наведені цифри великі, оскільки вони означають майже повне знищення всіх елементів обов'язку i ладу, силою яких командний склад міг ще якось підтримувати в армії хоча б незначний порядок. 3 вибуттям цих елементів 7-а, 8-а та 11-а армії перетворилися на абсолютно нестійку юрбу, готову тікати від першого ж натиску противника [9, с. 472]. 
Значення російського наступу у червні 1917 р. добре сформульовано у праці О. Будберга: «У червні-липні окремими ударами наших (російських - А.Н.) останніх наступів, проведених на вимогу стурбованих союзників, ми так стривожили німецьке верховне командування, що воно вирішило покінчити остаточно з Росією і цим розв'язати собі руки на Сході. Престиж наш навіть у цей час був ще настільки великий, що для виконання такої операції німці визнали необхідним і ризикнули зняти з західного фронту і перекинути проти нас шість дивізій» [5, с. 23]. Твердження О. Будберга відносно російського престижу саме на час наступу виглядає перебільшенням, адже західні союзники мали можливість скласти уявлення про дійсний стан Російської армії після Лютневої револющії, проте незаперечно і те, що діяльність військ російського фронту, в тому числі і Південно-Західного, ще продовжувала мати значення для всього ходу війни, що і підтверджуеться поведінкою союзників, реакцією противника та наведеними прикладами дій військ.

Висновки. У 1917 р. Південно-Західний фронт продовжував мати значення для подальшого ходу війни. Це добре знали і політичні союзники тепер вже Російської республіки, а відтак і ставили новим іï політичним провідникам відповідні вимоги щодо чергового наступу.

Російське командування з усією відповідальністю поставилося до підготовки наступу. Ї̈̈ вважають зразковою. Наступ організовувався ретельно, все було продумано до найменших дрібниць. Особливо вражає підготовка артилерії. На чолі фронту та чотирьох його армій стояли досвідчені военачальники, які вміло керували військами. Постачання військ всім необхідним було налагоджено набагато краще, ніж у попередні роки. Ці та багато інших обставин давали військам Південно-Західного фронту значні шанси на перемогу. Проте не було враховано найголовніший чинник морально-психологічний стан військ. Рівень військової дисципліни постійно знижувався. Війська вже були під впливом револющійних свобод без обов'язків, воювати не хотіли 
і не виконували накази командування, обговорюючи їх на мітингах. Фактично війська втомилися від тривалої війни і ніяка урядова пропаганда не давала у цьому відношенні позитивних результатів. Військові керівники бачили цей фрактичний розвал могутньої дотепер армії, але перешкодити йому вже не могли. Тому червневий наступ 1917 р. i не досяг бажаних результатів.

Під час цього наступу яскраво проявив себе український чинник. Військові частини, згуртовані на національній основі, порівняно з іншими добре і 3 самопожертвою виконували свої завдання. Проте уряд і командування поставилися до українського військового руху лище як до засобу досягнення мети. При цьому внесок саме українських частин у результати боїв майже постійно замовчувався. Це свідчить про те, що Тимчасовий російський уряд нехтував українськими нащіональними інтересами і не визнавав українських прагнень.

1. Стратегический очерк войны 1914-1918 гг. Ч. 7. Кампания 1917 г. Составил А. М. Зайончковский.- М. 1923

2. Аверченко С. Юрий Гильшер - один из первых асов России // Военно-исторический журнал. 2001. №8. С.38-47;

3. Агеев А., Вержховский Д., Виноградов В. и др. История первой мировой войны 1914 - 1918 гг. / Под ред. доктора исторических наук И.И. Ростунова. - Москва: Наука, 1975. - 712 c;

4. Брусилов $A$. Мои воспоминания: Воспоминания. Мемуары / Алексей Алексеевич Брусилов. - Мн.: Харвест, 2003. - 432 c;

5. Будберг А. Вооруженные силы Российской Империи в исполнении общесоюзных задач и обязанностей во время войны 1914-17 г. Режим доступу: http://www. grwar. ru/library/Budberg/index.html;

6. Велика війна 1914 - 1918 рр. і Україна: У двох книгах. - Книга 2: Мовою документів і свідчень. - К.: ТОВ «Видавництво «Кліо», 2015. - 800 с;

7. Галаган M. 3 моїх споминів (1880-ті - 1920 р.): Документально-художне видання / Передмова Т. Остапко, В. Соловйова. - К.: Темпора, 2005. - 636 c; 
8. Геруа Б. Воспоминания о моей жизни. Т.2, Париж, 1969;

9. Головин $H$. Россия в Первой мировой войне / Николай Головин. - М.: Вече, 2006. - 528 с.

10. Дорошенко Д. Історія України, 1917-1923. В 2-х т.: Т. 1, Період Центральної Ради. - Ужгород, 1932; НьюЙорк, 1954. - 437 с.

11. Дорошенко Д. Мої спомини про недавне минуле (1914-1920 роки): Науково-популярне видання. - К.: Темпора, 2007. - 632 с.

12. Зайончковский $A$. Первая мировая война / Зайончковский А. - СПб.: ООО «Издательство «Полигон», 2002. - 878 с. Режим доступу: http://militera.lib.ru/h/ zayonchkovskyl/index.html

13. Залесский $K$. Первая мировая война. Биографический энщиклопедический словарь - М.: Вече, 2000. $576 \mathrm{c.}$

14. Залесский $K$. Кто был кто в Первой мировой войне / К.А. Залесский. - М.: ООО «Изд-во АСТ»: ООО «Изд-во Астрель», 2003. - 894 с.

15. Кедровський В. 1917 рік. Спогади члена Українського військового генерального комітету і товариша секретаря військових справ у часі Української Центральної Ради. - Вінніпег, 1967. - 526 с.

16. Керсновский $A$. История Русской Армии. - М.: Воениздат, 1994. - Т. 4. - 338 с.

17. Кочубей В. Генерал Я. Г. Гандзюк // Военная быль. - март 1966. - № 78. - С. 14-17; № 79. - С. 17-21.

18. Кочубей В. Генерал Павел Петрович Скоропадский // Военная быль. - март 1966. - № 95. - С. 18-24.

19. Людендорф Э. Мои воспоминания о войне 19141918 гг. - М.: АСТ. Мн.: Харвест, 2005. - 800 с.

20. Никольский $C$. «Муромщы» в бою: Подвиги русских авиаторов / Сергей и Михаил Никольские. - М.: Сксмо: Яуза, 2010. - 384 c.

21. Перша світова війна 1914 - 1918 рр. і Україна. Українські землі у центрі цивілізаційної кризи / Упоряд. О. П. Реєнт. - К.: ТОВ «Видавництво Кліо», 2015. - 64 с.

22. Ростунов И. Русский фрронт Первой мировой войны. - М.: Издательство «Наука», 1976. - 387 с.

23. Скоропадський П. Спогади. Кінець 1917 грудень 1918. Київ-Філадельфія. - 1995. - 494 с. 
Рецензент: Ю.В. Бураков, кандидат історичних наук, доцент, провідний науковий співробітник Наукового центру Національної академії сухопутних військ імені гетьмана Петра Сагайдачного, м. Львів.

\section{Naumenko Andriy}

\section{TROOPS OF THE RUSSIAN SOUTH-WESTERN FRONT IN THE J UNE OF THE OCCASION OF 1917}

The article deals with the combat activity of the Russian troops of the Southwestern Front in the J une offensive of 1917 on Ukrainian lands during the First World War. The work is analyzed in which the given issue is covered in different ways, the conditions for preparing and conducting the offensive, the participation of troops in the fighting at the front is pushed, and their contribution to the results of battles is studied.

Keywords: Russian army, World War I, campaign of 1917, army, corps, division, infantry, artillery, aviation. 